\title{
Effect of Instructional Supervisory Practices on Teacher Motivation in Private Secondary Schools of Lahore, Pakistan
}

\author{
Shahida Nasreen \\ University of Management and Technology \\ Dr. Madiha Shah \\ University of Management and Technology
}

\begin{abstract}
Research in the area of school leadership proves that effective leaders accomplish the role of instructional leaders (Zheng, 1996). The main objective of an effective principal is the supervision of classroom instructions (Hoy, \& Hoy, 2006). This paper examines the effect of instructional supervisory practices of the school leaders on teacher motivation in private secondary schools of Lahore, Pakistan. Twenty four schools from three different school types (low-income schools, middle-class schools, and elite schools) were selected using stratified random sampling. A questionnaire comprising of two scales, Instructional Supervisory Practices Scale (ISPS) and Work Extrinsic and Intrinsic Motivation Scale (WEIMS), was used to collect data from 530 teachers. Descriptive as well as inferential statistics were used to obtain results. The teachers' perceptions regarding their leaders' instructional supervisory practices and the level of teacher motivation were determined by computing mean and standard deviation. The Pearson Correlation (r) was computed to explore the relationship between six subscales of instructional supervisory practices and teacher motivation. The results of the study indicated a significant positive relationship between instructional supervision and teacher motivation. It is concluded that instructional supervision significantly contributes to teacher motivation.
\end{abstract}

Keywords: Instructional Supervision, Teacher Motivation, Private School, Pakistan.

\section{INTRODUCTION}

Instructional supervision provides guidance to teachers and helps them to enhance their teaching practices that ultimately improve students' academic performance (Peretomode, 2001). Instructional supervision is considered as an expert help (Oliva, \& Pawlas, 2004) that makes teaching and learning process more effective (Beach, \& Reinhartz, 2000). Mutual respect, cooperation, and collaboration help to build and strengthen the bond between the supervisor and the supervisee (Beach, \& Reinhartz, 2000). Supervision enables the novice teachers to become responsible and self-directing who can work proficiently with the minimum supervision in future (Oye, 2009).

Teacher Motivation, on the other hand, is defined in terms of "attraction, retention, and concentration as something that determines what attracts individuals to teaching, how long they remain in their initial teacher education courses and subsequently the teaching profession, and the extent to which they engage with their courses and the teaching profession" (Sinclair, 2008). Teacher motivation has been affirmed as one of the most important determinants of student learning outcomes (Bennell, \& Akyeampong, 2007; Guajardo, 2011), teachers' job performance (Inayatullah, \& Jehangir, 2012; Nyakongo, 2015) and students' performance/achievement (Gitonga, 2012; Taştan et al., 2018). 


\section{Instructional Supervision}

\section{LITERATURE REVIEW}

Instructional supervision is referred to as a set of activities that are aimed at improving the teaching and learning process for the students (Archibong, 2012). A supervisor is "a change agent" who is accountable to arrange required resources for the teachers and enable them to realize the need for change, to test out the worth of change, and to develop strategies for the change. All the techniques or procedures used by the supervisors to supervise the teachers are collectively considered as supervisory practices (Beach, \& Reinhartz, 2000). To Oliva and Pawlas (2004), supervisory practices are the provision of assistance to the teachers by the experts in refining their instructions. Instructional Supervision is a process that provides adequate guidance to teachers to improve students' performance and academic results (Peretomode, 2001). Supervisory practices used by the supervisors should be based on their personal beliefs and philosophies about supervision (Glickman, Gordon, \& Ross-Gordon, 2001).

During the last few decades, bounteous research has been conducted in the field of instructional leadership. The school leaders as instructional supervisors are believed to bring improvement in their schools (Leithwood, Harris, \& Hopkins, 2008). Researchers have linked educational instructional supervision with teachers' professional development (Kutsyuruba, 2003), teachers' effectiveness (Ikegbusi, Gloria, Eziamaka, \& Nonye, 2016; Ghavifekr, \& Ibrahim, 2014; Veloo, Komuji, \& Khalid, 2013; Oye, 2009), quality enhancement (Samoei Sr.,2014; Mukoro, \& Ogheneovo, 2013; Archibong, 2012) and teacher motivation (Esia-Donko, \& Baffoe, 2018; Ariffin, Idris, \& Abdullah, 2015; Ghavifekr, \& Ibrahim, 2014).

Kutsyuruba (2003) claimed that effective matching of supervision models to teachers' needs resulted in enhanced professional development. Oye (2009) observed that teachers' classroom performance was highly affected by the use of instructional supervision as well as by the material suggested by the instructional supervisors. Veloo, Komuji, and Khalid (2013) also supported that clinical supervision makes teaching and learning more effective. Ghavifekr and Ibrahim (2014) verified that the head of departments' instructional supervisory role was positively correlated with teachers' job performance. Usman (2015) found a correlation between regular instructional supervision and teachers' performance among senior secondary school teachers in Nasarawa state of Nigeria.

Pearce (2017) measured the effect of instructional leadership on teacher efficacy. He used a mixed-method approach on a sample of 29 principals and 109 teachers in Cobb County of Georgia, USA. The results of the Multiple Regression Analysis indicated no significant impact of instructional leadership on teacher efficacy. However, the answer to an open-ended question revealed that both, the teachers and the principals, perceived certain leadership behaviors to be a strong positive predictor of teacher efficacy.

Limited research has been found on instructional leadership in the education sector in developing countries like Pakistan. Khan (2013) conducted qualitative research to explore core issues related to the instructional leadership in public schools in Pakistan. In this case study, the data was collected through various means; the participants were interviewed formally and informally, the concerned documents were reviewed and events were explored. The findings revealed that the headteachers contributed inadequately to improving the instructional value of their schools although the necessary resources were available. The uncertainty of the headteachers' roles, inadequate capacity building opportunities, and a deficiency of an accountability mechanism were recognized as the sources of their weaknesses. The study suggested that school principals ought to be equipped with the essential skills and knowledge that can facilitate the teaching and learning process. 
Recent research in the Pakistani context in the field of instructional leadership by Ali (2017) examined the relationship between school principals' instructional leadership on school effectiveness through the mediation of school culture. The study was conducted in Mardan, Pakistan. A direct positive relationship was found between instructional leadership and school effectiveness. The findings of the study revealed that school principals in Pakistan are not provided with the appropriate training. Ali (2017) suggests the researchers to probe further about how school leaders could develop instructional leadership skills with the minimum budget in developing countries like Pakistan.

\section{Teacher Motivation}

Motivation is an internal stimulus that triggers or boosts behavior and provides it a direction (Kleinginna, \& Kleinginna, 1981). It is a yearning for learning (Wlodkowski, \& Jaynes, 1990). It is an internal condition that starts, directs, and sustains behavior (Green, 2002) or a state that assists in the development of high achievement (Gagne, 2004). Based on the goals or reasons that lead to action, Deci and Ryan (1985) have divided motivation into two types; intrinsic motivation and extrinsic motivation. Intrinsic motivation refers to the motivation that creates enjoyment and satisfaction in an activity while extrinsic motivation is mostly derived from the external concerns of the activity. According to Self Determination Theory (SDT) proposed by Deci and Ryan (1985), extrinsic motivation can further be categorized into four types; integrated regulation, identified regulation, introjected regulation, and external regulation. Amotivation is a condition that reflects the absence of intent for an action (Deci, \& Ryan, 1985).

Alam and Farid (2011) conducted a study in Rawalpindi, Pakistan to examine the factors that affect teacher motivation. Socio-economic status of the teachers, their selection of the profession, learners' behavior and examination stress were found to be the main factors affecting teacher motivation. Adjei and Amofa (2014) researched to find out the factors that affected teacher motivation in senior high schools of Cape Coast, Ghana. Their study showed that involvement in decision-making, credit for good work, healthy working environment, and pays/salaries were the main factors that contributed to teacher motivation. Another study conducted in Africa identified developmental, environmental, leadership, and remuneration factors as the main factors that affect teacher motivation (Matoke, Okibo, \& Nyamongo, 2015).

Inayatullah and Jehangir (2012) studied public and private schools of Peshawar, Pakistan and concluded that a positive relationship existed between teacher motivation and teacher job performance. The motivation was found to be a central element in enhancing teachers' commitment to job performance in public secondary schools of Kenya (Nyakongo, 2015).

\section{Instructional Supervision and Teacher Motivation}

Teacher satisfaction is directly related to teacher motivation (Shah, Akhtar, Zafar, \& Riaz, 2012; Rusu, \& Avasilcai, 2013; Saka, \& Salman, 2014). A study was conducted in Malaysia and China simultaneously by Hamzah, Wei, Ahmad, Hamid, and Mansor (2013) that showed a positive but medium relationship between supervisory practices and teacher satisfaction among teaching staff in Kuala Lumpur, Malaysia, while a positive and strong relationship among teachers in Hefei, China.

Ghavifekr and Ibrahim (2014) found a strong positive relationship between the head of the department's instructional supervisory role and teacher motivation which contributed to the teachers' job performance in private secondary schools of Kuala Lumpur, Malaysia. Ariffin, Idris, and Abdullah (2015) surveyed 261 secondary school teachers in Labuan and Seremban, Malaysia. A correlation analysis revealed a statistically significant positive relationship between teacher motivation and teaching supervision. 
Esia-Donkoh and Baffoe (2018) conducted a study in public schools of Mfantseman Municipality, Ghana. Both the headteachers and teachers were given two sets of questionnaires to gather information about instructional supervision and teacher motivation respectively. The results indicated a significant positive but weak relationship between the supervisory practices of the headteachers and teacher motivation.

\section{STATEMENT OF THE PROBLEM}

Pakistan is a developing country facing several problems in the education sector (Rasool, 2007). Research in the area of school leadership and management has indicated that one of the main reasons of school ineffectiveness in Pakistan is the scarcity of competent and qualified leaders who could initiate educational programs more effectively (Rizvi, 2010). Principal's role as an instructional leader is considered crucial to overcome problems, increase the school capacity, develop teachers' competencies, and to provide an environment that facilitates the teaching and learning process (Niqab, Sharma, Mei, \& Maulod, 2014).

To bring improvement in the education sector, more focus should be given to the supervisory role of a school principal. The current study intends to identify the private secondary school teachers' perceptions regarding instructional supervisory practices of their heads/supervisors in their schools. The study examines how these perceptions affect teacher motivation.

Simkins and Memon (2003) claimed that principals in the government sector in Pakistan usually neglect curriculum designing and instructional supervision of the schools and spend most of their time in performing administrative roles. However, Iqbal (2012) defended private schools by claiming that private schools delivered quality education mainly due to quality of monitoring system and effective instruction. The current study is limited to the private sector as the research was intended to evaluate instructional supervision that is expected to be practiced in private sector.

Private schooling is a significant feature of the educational landscape in Pakistan as one-fifth of all school-going children join private schools (Nguyun, \& Raju, 2014). The province of Punjab has the highest private school participation rate for both 6-10 and 11-15 age groups (Nguyun, \& Raju, 2015). The selected sample is taken from Lahore as this city is ranked as third in 2017 District Education Ranking in Pakistan (Alifailaan, 2017)

\section{PURPOSE OF THE STUDY}

The primary purpose of this study was to identify the instructional supervisory practices of the private secondary schools' supervisors/heads and to examine the level of teacher motivation. The nature and extent of the relationship that existed between instructional supervision and teacher motivation (if any) were determined.

\section{OBJECTIVES OF THE STUDY}

The objectives of the study were:

1. To identify the teachers' perceptions regarding instructional supervisory practices of their supervisors/heads in private secondary schools of Lahore, Pakistan.

2. To identify the level of teacher motivation towards the teaching profession in private secondary schools of Lahore, Pakistan.

3. To determine the relationship between teachers' perceptions regarding instructional supervisory practices and teacher motivation in private secondary schools of Lahore.

4. To examine the effect of teachers' perceptions regarding instructional supervisory practices on teacher motivation in private secondary schools of Lahore. 


\section{Research Questions}

The current study seeks to answer the following research questions:

1. What are the teachers' perceptions regarding instructional supervisory practices of their supervisors/heads in private secondary schools of Lahore?

2. What is the level of teacher motivation towards the teaching profession in private secondary schools of Lahore?

3. What is the relationship between teachers' perceptions regarding instructional supervisory practices and teacher motivation in private secondary schools?

4. What is the effect of teachers' perceptions regarding instructional supervisory practices on teacher motivation in private secondary schools?

\section{Sampling Procedure}

\section{METHODOLOGY}

A quantitative survey method was used to collect data from private secondary school teachers. Stratified random sampling technique was used to select 24 schools from three types of private schools. These three types included low-income schools that cater to the educational needs of low-income families, the middle-class schools focusing on middle-income group and elite schools that target the children of the affluent society. More than 600 questionnaires were distributed among teachers, out of which 530 were filled and returned back making the response rate of $87 \%$.

\section{Instrumentation}

To examine the perceptions of the teachers about the instructional supervision being practiced in their schools, a scale originally developed by Baffour-Awuah (2011) was adapted for this study. The actual questionnaire consisted of 24 items enquiring what experiences the participants had regarding instructional supervision in their school (reality) and how they wanted their supervisors to act (ideal). However, the format of the questionnaire was changed focusing on the purpose of this research. The aspect demanding the participants' real experience only with instructional supervision was used. The scale comprised of 24 items ranging under six subscales: (i) Traditional Supervision Practices, (ii) Assistance and Support, (iii) Oversight in Supervision, (iv) Leadership Skills, (v) Professional Development, and (vi) Collaboration in Supervision. These subscales indicated the frequency and/or level of certain practices as exhibited by the supervisors. All of the 24 items were rated on a 5-point Likerttype scale as; $1=$ Never, $2=$ Rarely, $3=$ Sometimes, $4=0$ ften, and $5=$ Always.

Work Extrinsic and Intrinsic Motivation Scale (WEIMS) consisting of 18 items was adopted to measure teacher motivation. The items in this scale were clustered in six subscales: (i) Intrinsic Motivation, (ii) Integrated Regulation, (iii) Identified Regulation, (iv) Introjected Regulation, (v) External Regulation, and (vi) Amotivation. It was rated on a 5-point Likert-type scale ranging from strongly disagree to strongly agree.

As English is a second language in Pakistan, both the questionnaires were translated to Urdu (the local language) to ensure maximum understanding of all the items.

\section{LIMITATIONS OF THE STUDY}

The study covered only private secondary schools of Lahore, therefore, the results might not be applied to the public education sector across Pakistan. The research design is quantitative which provides a snapshot of the phenomenon, whereas qualitative research on the topic could have explored complex reality related to instructional supervisory practices and teacher motivation. 


\section{RESULTS AND INTERPRETATIONS}

Data gathered through two scales were analyzed using SPSS version 20. The level of teachers' perceptions regarding instructional supervisory practices and teacher motivation was determined using descriptive statistics i.e., mean and standard deviation. The Pearson Correlation was computed to examine the relationship between instructional supervisory practices and teacher motivation. Regression test was applied to determine whether teachers' perceptions regarding instructional supervisory practices significantly contribute toward teacher motivation.

\section{Teachers' Perceptions Regarding Instructional Supervisory Practices}

Most frequently observed instructional supervisory practices with the highest mean values included Leadership Skills $(M=4.14, S D=.84)$, Oversight in Supervision $(M=4.01, S D=.74)$, Assistance and Support $(M=3.96, S D=.66)$, Collaboration in Supervision $(M=3.96, S D=.83)$, Traditional Supervisory Practices $(M=3.76, S D=.99)$, and Professional Development $(M=$ $3.64, S D=.81$ ) respectively.

Responses of the participants to the items in Leadership Skills subscale identified that teachers believed that their supervisors treated them professionally with a sense of care and respect. Responses to Oversight in Supervision subscale illustrated that the supervisors evaluated teachers' classroom instructional practices and content knowledge while ensuring that teachers made good use of their instructional time. Assistance and Support subscale showed that the majority of the teachers agreed that their supervisors helped them find solutions to their problems and made themselves readily available for advice and instructional support. However, regarding the provision of research material about teaching instructions, the majority of the teachers denied such support from their supervisors.

Table 1: Responses of the Participants to each Sub-scale in Instructional Supervisory Practices Scale

\begin{tabular}{lcc}
\hline Sub-scales in ISPS & $\begin{array}{c}\text { Mean } \\
(\boldsymbol{M})\end{array}$ & $\begin{array}{c}\text { Std. Deviation } \\
(\boldsymbol{S D})\end{array}$ \\
\hline Traditional Supervisory Practices & 3.76 & .99 \\
Assistance \& Support & 3.96 & .66 \\
Oversight in Supervision & 4.01 & .74 \\
Leadership Skills & 4.14 & .84 \\
Professional Development & 3.64 & .81 \\
Collaboration in Supervision & 3.96 & .83 \\
\hline
\end{tabular}

$N=530$

Teachers' perceptions on Collaboration in Supervision subscale indicated that most of the supervisors performed collaborative activities, like engaging teachers in mutual dialogue and observations, arranging conferences with them to meet and share ideas about instruction. Traditional Supervisory Practices subscale showed that supervisors use their control to affect teachers' instructional practices and inspect teachers' instructional practices for finding errors. Regarding Professional Development, the majority of the participants felt that their supervisors often demonstrated teaching techniques to them and arranged workshops for inservice teachers to develop their skills. The item inquiring the implementation of Action Research, almost $40 \%$ of the teachers opined that such activities were performed in their organizations.

\section{Teachers' Perceptions Regarding Teacher Motivation}

The respondent teachers had higher Intrinsic Motivation $(M=4.30, S D=.61)$ than extrinsic motivation. Among the extrinsic motivation, the teachers showed the highest level of Integrated Regulation $(M=4.16, S D=.74)$ followed by Introjected Regulation $(M=4.12, S D=$ 
1.00), Identified Regulation $(M=4.03, S D=.72)$, and External Regulation $(M=3.80, S D=.89)$ respectively. Amotivation $(M=3.10, S D=.92)$, lack of motivation, was reported to have the least mean based on the participants' responses.

Table 2: Responses of the Participants to Work Extrinsic and Intrinsic Motivation Scale

\begin{tabular}{lcc}
\hline Sub-scales in TM & $\begin{array}{c}\text { Mean } \\
(\boldsymbol{M})\end{array}$ & $\begin{array}{c}\text { Standard Deviation } \\
(\boldsymbol{S D})\end{array}$ \\
\hline Intrinsic Motivation & 4.30 & .61 \\
Integrated Regulation & 4.16 & .74 \\
Identified Regulation & 4.03 & .72 \\
Introjected Regulation & 4.12 & 1.00 \\
External Regulation & 3.80 & .89 \\
Amotivation & 3.10 & .92 \\
\hline$N=530$ & &
\end{tabular}

The results derived from the Work Extrinsic and Intrinsic Motivation Scale (WEIMS) indicated that a large majority (92\%) of the respondents derived pleasure from learning new things. Most of the teachers perceived their job to be a fundamental part of their personality (83\%) and also of their life (85\%). Identified regulation also played a great part (76\%) to build up teacher professional motivation. Introjected Regulation depicted that a great majority of private secondary school teachers (79\%) applied self-imposed pressures to avoid guilt or maintain self-esteem. Regarding External Regulation, around $80 \%$ of the teachers reflected that the teaching profession provided them security.

\section{Relationship between Instructional Supervision and Teacher Motivation}

The Pearson Correlation $(r)$ was computed to explore the relationship between six sub-scales of instructional supervisory practices and teacher motivation. The result of the Pearson Correlation Coefficient $(r)$ is mentioned in Table 3. To test the assumption, whether instructional supervisory practices are correlated with teacher motivation, all the six subscales of teacher motivation were summed up and their average was calculated.

Table 3 Results of the Pearson Correlation (r)

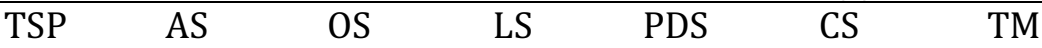

\begin{tabular}{lcccccc}
\hline TSP & - & & & & & \\
AS & $.439^{* *}$ & - & & & & \\
OS & $.544^{* *}$ & $.554^{* *}$ & - & & & \\
LS & $.203^{* *}$ & $.604^{* *}$ & $.440^{* *}$ & - & & \\
PD & $.428^{* *}$ & $.584^{* *}$ & $.576^{* *}$ & $.565^{* *}$ & - & \\
CS & $.449^{* *}$ & $.635^{* *}$ & $.662^{* *}$ & $.630^{* *}$ & $.698^{* *}$ & - \\
TM & $.353^{* *}$ & $.309^{* *}$ & $.351^{* *}$ & $.362^{* *}$ & $.370^{* *}$ & $.402^{* *}$
\end{tabular}

Note. ${ }^{* *}$ Correlation is significant at the 0.01 level (2-tailed).

TSP $=$ Traditional Supervisory Practices, AS = Assistance and Support, $\mathrm{OS}=$ Oversight in Supervision, $\mathrm{LS}=$ Leadership Skills, $\mathrm{PD}=$ Professional Development, $\mathrm{CS}=$ Collaboration in Supervision, $\mathrm{TM}=$ Teacher Motivation 
The results in Table 3 show that there existed a significant positive relationship between each sub-scale of instructional supervision and teacher motivation. The strength of this relationship ranged from $0.309^{* *}$ (between Assistance and Support and Teacher Motivation) to 0.402** (between Collaboration in Supervision and Teacher Motivation) where $p<.01$. The results indicated that an increase in instructional supervision results in greater teacher motivation or vice versa.

\section{Effect of Instructional Supervision on Teacher Motivation}

A Multiple Regression Analysis was conducted to determine the effect of instructional supervision on teacher motivation. Six sub-scales of Instructional Supervisory Practices Scale were treated as independent variables and their effect on teacher motivation, a dependent variable, is displayed in Table 4, Table 5, and Table 6.

Table: 4 Model Summary

\begin{tabular}{ccccc}
\hline Model & $\mathrm{R}$ & R Square & Adjusted R Square & Std. Error of the Estimate \\
\hline 1 & $.480^{\mathrm{b}}$ & .231 & .222 & .49 \\
\hline
\end{tabular}

a. Dependent Variable: Teacher Motivation

b. Predictors (Constant): Traditional Supervisory Practices, Assistance and Support, Oversight in Supervision, Leadership Skills, Professional Development, Collaboration in Supervision

Model Summary shows that $23.1 \%$ of the variation (R Square $=0.231$ ) in the dependent variable (TM) can be predicted by the independent variables (TSP, AS, OS, LS, PD, and CS). These variables have a significant effect on teacher motivation.

Table 5 displays all the statistics of ANOVA as part of Multiple Regression Analysis. The results of the analysis indicated that there was a significant linear regression relationship $(\mathrm{F}=26.066$, $p<.001$ ) between independent and dependent variables.

Table: 5 Multiple Regression Analysis between Dependent and Independent Variables ANOVAa

\begin{tabular}{llccccc}
\hline Model & & Sum of & df & Mean Square & F & Sig. \\
& & Squares & & & & \\
\hline \multirow{2}{*}{1} & Regression & 37.739 & 6 & 6.290 & 26.066 & $.000^{* \mathrm{~b}}$ \\
& Residual & 125.958 & 522 & .241 & & \\
& Total & 163.698 & 528 & & & \\
\hline
\end{tabular}

*. $\mathrm{P}<.001$

a. Dependent Variable: Teacher Motivation (TM)

b. Predictors (Constant): Traditional Supervisory Practices, Assistance and Support, Oversight in Supervision, Leadership Skills, Professional Development, Collaboration in Supervision

The coefficients vary between .228 between Traditional Supervisory Practices (TSP) and Teacher Motivation (TM), -.070 between Assistance and Support (AS) and Teacher Motivation (TM), .037 between Oversight in Supervision (OS) and Teacher Motivation (TM), .215 between Leadership Skills (LS) and Teacher Motivation (TM), .081 between Professional Development (PD) and Teacher Motivation (TM), and .127 between Collaboration in Supervision (CS) and Teacher Motivation (TM). Two out of these six regression coefficients i.e. Traditional Supervisory Practices (TSP) and Leadership Skills (LS) were significant $(p<.001)$ suggesting that these subscales were the strongest predictors of teacher motivation. 
Table: 6

Coefficients ${ }^{a}$

\begin{tabular}{|c|c|c|c|c|c|c|}
\hline \multicolumn{2}{|c|}{ Model } & \multicolumn{2}{|c|}{$\begin{array}{l}\text { Unstandardized } \\
\text { Coefficients }\end{array}$} & \multirow{2}{*}{$\begin{array}{c}\text { Standardized } \\
\text { Coefficient } \\
\text { Beta }\end{array}$} & \multirow[t]{2}{*}{$\mathrm{t}$} & \multirow[t]{2}{*}{ Sig. } \\
\hline & & B & Std. Error & & & \\
\hline \multirow{7}{*}{1} & TM & 2.43 & .145 & & 16.740 & $.000^{*}$ \\
\hline & TSP & .13 & .027 & .228 & 4.717 & $.000^{*}$ \\
\hline & AS & -.06 & .048 & -.070 & -1.254 & .211 \\
\hline & OS & .03 & .043 & .037 & .658 & .511 \\
\hline & LS & .14 & .036 & .215 & 3.914 & $.000^{*}$ \\
\hline & PDS & .06 & .040 & .081 & 1.420 & .156 \\
\hline & $\mathrm{CS}$ & .09 & .044 & .127 & 1.935 & .054 \\
\hline
\end{tabular}

*. $p<.001$

Note. Dependent Variable: Teacher Motivation (TM)

Predictors (Constant): TSP $=$ Traditional Supervisory Practices, AS = Assistance and Support, OS = Oversight in Supervision, LS = Leadership Skills, PDS = Professional Development Skills, $\mathrm{CS}=$ Collaboration in Supervision

\section{RESULTS AND FINDINGS}

The most frequently observed instructional supervisory practice with the highest mean value was Leadership Skills (LS), while Professional Development (PD) had the lowest mean.

The results of the Pearson Correlation $(r)$ indicated that there existed a significant positive relationship between instructional supervisory practices and teacher motivation. The current study substantiated the results given by Ibraim and Ghavifekr (2014); Ariffin, Idrisand, and Abdullah (2015) and Esia-Donkoh and Baffoe (2018). It was also discovered that the maximum correlation $\left(.402^{* *}\right)$ existed between the sub-scale named as "Collaboration in Supervision (CS)" and Teacher Motivation (TM). Overall, the results illustrated that effective instructional supervision will lead to greater teacher motivation and vice versa.

The results of the Multiple Regression Analysis showed that all six sub-scales of instructional supervisory practices had a significant effect on teacher motivation. Traditional Supervisory Practices (TSP) and Leadership Skills (LS) were found to be the strongest predictors of teacher motivation. The present study validates the work of Matoke, Okibo, and Nyamongo (2015) which claimed that instructional supervision positively affects teacher motivation.

\section{CONCLUSION, RECOMMENDATIONS AND SUGGESTIONS}

Most of the instructional supervisory practices are frequently practiced by the supervisors/heads in private secondary schools of Lahore. The teachers in these schools are more intrinsically motivated. A significant positive relationship exists between instructional supervision and teacher motivation. Therefore, it is concluded that instructional supervision of headteachers could enhance motivation among teaching staff.

As instructional supervision is a holistic process, only the principals must not be considered accountable for supervision. The principals should share this burden with their deputy heads, coordinators/head of the departments, etc. In this regard, school supervisors should be provided with extensive training on the role of effective supervision.

The school supervisors should work on building inter-personal relationships with their staff and address them with great respect and care as it will arouse their motivational spirit. The supervisors should not inspect their teachers teaching for finding faults in their instructional 
practices, rather it should be used to build congenial relationships with the staff. Any mistakes in teaching instruction should be pointed out later in a lighter tone in post-observational meetings.

It is recommended that the school supervisors must implement action research in their organizations. In this way, they can make their staff more independent and equip them with better problem-solving skills. Teachers should be provided with updated research materials like journal research articles and books etc.

Further studies should be conducted to evaluate the instructional supervisory practices from the perspective of supervisors and examine their effectiveness, especially in the public sector. More research is required to explore the barriers of instructional supervision in schools. Furthermore, qualitative research is recommended to explore the dimensions of both supervisory practices and teacher motivation.

\section{References}

Adjei, H., \& Amofa, A. K. (2014). Teacher motivation in senior high schools in the Cape Coast Metropolis. Eur. J. Educ. Dev. Psychol, 2(1), 18-25.

Alam, M. T., \& Farid, S. (2011). Factors affecting teachers motivation. International Journal of Business and social science, 2(1), 298-304.

Ali, N. (2017). Teachers' perceptions of the relationship between principals' instructional leadership, school culture and school effectiveness in secondary schools in Pakistan (Doctoral dissertation, University of Malaya).

Archibong, F. I. (2012). Instructional supervision in the administration of secondary education: A panacea for quality assurance. European Scientific Journal, ESJ, 8, 13.

Ariffin, A. K., Idrisb, A. R., \& Abdullah, Z. (2015). The relationship between teaching supervision with teachers' motivation in secondary schools. Journal of Advanced Research in Social and Behavioural Science, 1, 1-11.

Baffour-Awuah, P. (2011). Supervision of instruction in public primary schools in Ghana: Teacher's and headteacher's perspectives (Doctoral dissertation, Murdoch University).

Beach, D. M., \& Reinhartz, J. (2000). Supervisory leadership: Focus on instruction. Toronto, ON: Allyn and Bacon.

Bennell, P., \& Akyeampong, K. (2007). Teacher motivation in sub-Saharan Africa and South Asia (No. 71). London: DfID.

Deci, E. L., \& Ryan, R. M. (1985). The general causality orientations scale: Self-determination in personality. Journal of research in personality, 19(2), 109-134.

Esia-Donkoh, K., \& Baffoe, S. (2018). Instructional supervisory practices of headteachers and teacher motivation in public basic schools in Anomabo Education Circuit. Journal of Education and e-Learning Research, 5(1), 43-50.

Gagné, F. (2004). Transforming gifts into talents: The DMGT as a developmental theory. High Ability Studies, 15, 119-147.

Gitonga, D. W. (2012). Influence of teachers' motivation on students' performance in Kenya certificate of secondary education in public secondary schools in Imenti South District Kenya. Unpublished M. Ed Project, Nairobi: University of Nairobi.

Glickman, C. D., Gordon, S. P., \& Ross-Gordon, J. M. (2001). Supervision and instructional leadership: A developmental approach. Allyn \& Bacon/Longman Publishing, a Pearson Education Company.

Green, E. C. (2002). The influence of individual and work environment characteristics on trainee motivation and training effectiveness measures (Doctoral dissertation, ProQuest Information \& Learning).

Guajardo, J. (2011). Teacher motivation: Theoretical framework, situation analysis of Save the Children country offices, and recommended strategies. Fairfield, CT: Save the Children.

Hamzah, M. I. M., Wei, Y., Ahmad, J., Hamid, A. H. A., \& Mansor, A. N. (2013). Supervision practices and teachers' satisfaction in public secondary schools: Malaysia and China. International Education Studies, 6(8), 92.

Hoy, A.W. \& Hoy, W. K. (2006). Instructional Leadership: A Research-based Guide to Learning in Schools (2nd edition). Boston, MA: Allyn \& Bacon. 
Ghavifekr, S., \& Ibrahim, M. S. (2014). Head of departments' instructional supervisory role and teachers' job performance: Teachers' perceptions. Asian Journal of Social Sciences and Management Studies, 1(2), 45-56.

Ikegbusi, N. G., Eziamaka, D., \& Nonye, C. (2016). The Impact of Supervision of Instruction on Teacher Effectiveness in Secondary Schools in Nigeria. International Journal of Advanced Research in Education \& Technology, 3(3), 12-16.

Inayatullah, A., \& Jehangir, P. (2012). Teachers' Job Performance: The Role of Motivation, Pakistani. Abasyn Journal of Social Sciences, 5(2), 78-99.

Khan, A. (2013). A case study of instructional contributions of community and government secondary school administrators in Pakistan. Journal of Education and Vocational Research, 4(2), 47-59.

Khan, A. (2015). Headteachers' beliefs and practices about teaching and learning in Pakistani public schools. Creative Education, 6(22), 2299-2312.

Kleinginna, P. R., \& Kleinginna, A. M. (1981). A categorized list of motivation definitions, with a suggestion for a consensual definition. Motivation and Emotion, 5(3), 263-291.

Kutsyuruba, V. V. (2003). Instructional supervision: Perceptions of Canadian and Ukrainian beginning highschool teachers (Doctoral dissertation, University of Saskatchewan).

Leithwood, K., Harris, A., \& Hopkins, D. (2008). Seven strong claims about successful school leadership. School leadership and management, 28(1), 27-42.

Matoke, Y. K., Okibo, W. B., \& Nyamongo, D. N. (2015). Determinants of teacher motivation in public secondary schools in Masaba South subcounty, Kenya. International Journal of Economics, Commerce and Management, 3(6), 139-160.

Mukoro, A. S., \& Ogheneovo, P. (2013). Instructional supervision as a catalyst for quality improvement in secondary educational settings. Journal of Educational and Social Research, 3(6), 59-67.

Niqab, M., Sharma, S., Wei, L. M., \& Maulod, S. B. A. (2014). Instructional leadership potential among school principals in Pakistan. International Education Studies, 7(6), 74-85.

Nyakongo, O. H. (2015). Influence of Motivation On teachers' job performance in public secondary schools in Rachuonyio South sub-county, Homa-Bay County: Kenya (Doctoral Dissertation, Kenyatta University).

Oliva, P. F., \& Pawlas, G. E. (2004). Supervision for today's schools.Jossey-Bass, An Imprint of Wiley. 10475 Crosspoint Blvd, Indianapolis, IN 46256.

Oye, O .0. (2009). Perceived influence of supervision of instruction on teachers' classroom performance in Ijebunorth education zone of Ogun state, (Doctoral Dissertation, University of Nigeria, Nsukka).

Pearce, M. L. (2017). The Effects of Instructional Leadership on Teacher Efficacy. Doctor of Education in Educational Leadership for Learning Dissertations. 5. Retrieved from https://digitalcommons.kennesaw.edu/educleaddoc etd/5

Peretomode, V. F. (2001). Introduction to Educational Administration, Planning and Supervision. Ikeja: Joja research and publishers ltd.

Rusu, G., \& Avasilcai, S. (2013). Human Resource Motivation: An Organizational Performance Perspectives, Annals of the Oradea University. Fascicle of Management and Technological Engineering, 22(12), 331-334.

Saka, K. A., \& Salman, A. A. (2014). An assessment of the levels of job motivation and satisfaction as predictors of job performance of library personnel in Nigerian universities. Journal of Balkan Libraries Union, 2(2), 26-33.

Samoeisr, C. J. (2015). Instructional supervisory role of principals and its'influence on students' academic achievement in public secondary schools in Nandi North District Nandi County Kenya (Doctoral dissertation).

Shah, M. J., Akhtar, G., Zafar, H., \& Riaz, A. (2012). Job satisfaction and motivation of teachers of public educational institutions. International Journal of Business and Social Science, 3(8), 271-281.

Simkins, T., Sisum, C., \& Memon, M. (2003). School leadership in Pakistan: Exploring the headteacher's role. School Effectiveness and School Improvement, 14(3), 275-291.

Rasool, G. R. (2007). Education in Pakistan: The key issues, problems and the new challenges. Journal of Management and Social Sciences 3(1), 47-55.

Sinclair, C. (2008). Initial and changing student teacher motivation and commitment to teaching. Asia-Pacific Journal of Teacher Education, 36(2), 79-104. 
Sule, M. A., Eyiene, A., \& Egbai, M. E. (2015). Instructional supervisory practices and teachers' role effectiveness in public secondary schools in Calabar South Local Government Area of Cross River State, Nigeria. Journal of Education and Practice, 6(23), 43-47.

Taştan, S. B., Davoudi, S. M. M., Masalimova, A. R., Bersanov, A. S., Kurbanov, R. A., Boiarchuk, A. V., \& Pavlushin, A. A. (2018). The impacts of teacher's efficacy and motivation on student's academic achievement in science education among secondary and high school students. EURASIA Journal of Mathematics Science and Technology Education, 14(6), 2353-2366.

Usman, Y. D. (2015). The impact of instructional supervision on academic performance of secondary school students in Nasarawa State, Nigeria. Journal of Education and Practice, 6(10), 160-167.

Veloo, A., Komuji, M. M. A., \& Khalid, R. (2013). The effects of clinical supervision on the teaching performance of secondary school teachers. Procedia-Social and Behavioral Sciences, 93, 35-39.

Wlodkowski, R. J., \& Jaynes, J. H. (1990). Eager to learn: Helping children become motivated and love learning. Jossey-Bass.

Zheng, H. Y. (1996). School Contexts, Principal Characteristics, and Instructional Leadership Effectiveness: A Statistical Analysis. Paper presented at the Annual Meeting of the American Educational Research Association (New York, NY, April 8-12, 1996). 